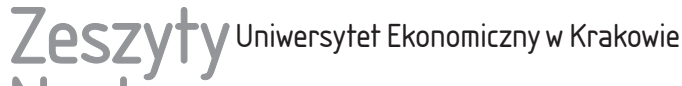 Naukowe
}

\section{Główne tendencje w handlu zagranicznym nowych państw członkowskich (UE-10) po akcesji do Unii Europejskiej}

\section{Streszczenie}

Celem artykułu było przedstawienie wyników analizy głównych tendencji w handlu zagranicznym państw UE-10 w okresie 10 lat od największego rozszerzenia Unii Europejskiej (2004-2013). Przystąpienie do Unii Europejskiej oznaczało znaczące zmiany w handlu nowych państw członkowskich (UE-10) - zarówno w handlu wzajemnym, z krajami UE-15, jak i z krajami trzecimi. Analizę skoncentrowano więc na rosnącej roli handlu zagranicznego jako jednego z istotnych czynników rozwoju gospodarczego krajów UE-10 oraz zwiększeniu integracji tych krajów z gospodarką światową. Badanie statystyczne dotyczyło analizy dynamiki importu i eksportu, struktury handlu w ramach grup towarowych SITC oraz BEC, wskaźników koncentracji (współczynnika Giniego oraz indeksu Herfindahla-Hirschmana), a także podobieństwa struktur wymiany. Wyniki przeprowadzonego badania pozwoliły na pozytywne zweryfikowanie tezy, że zmiany strukturalne będące konsekwencją liberalizacji handlu w ramach procesów integracyjnych UE przyczyniły się do poprawy pozycji konkurencyjnej państw UE-10.

Słowa kluczowe: handel międzynarodowy, integracja europejska, liberalizacja handlu, struktura wymiany handlowej.

\section{Wprowadzenie}

Nowe kraje członkowskie Unii Europejskiej zaliczane są do kategorii małych otwartych gospodarek, gdyż ważną rolę w pobudzaniu ich wzrostu odgrywa 
handel zagraniczny. Statystyki rachunków narodowych potwierdzają, że jednym z istotnych czynników odpowiedzialnych za utrzymywanie się wysokiej dynamiki PKB w tych państwach w latach 2004-2013 ${ }^{1}$ był eksport towarów i usług. $\mathrm{W}$ tym czasie rósł on bowiem znacznie szybciej niż popyt wewnętrzny. Zmiana roli krajów UE-10 w międzynarodowym podziale pracy, a w szczególności zwiększenie skali obrotów w ich zagranicznej wymianie handlowej, to przede wszystkim efekt rozwoju działalności korporacji międzynarodowych w regionie. Należy przy tym zaznaczyć, że do wzrostu zainteresowania korporacji krajami UE-10 istotnie przyczyniła się integracja z Unią Europejską.

Jeden z pierwszych etapów przygotowań do integracji handlowej w analizowanych krajach został rozpoczęty już w 1992 r., kiedy weszły w życie części handlowe Układów Europejskich ustanawiających stowarzyszenie ze Wspólnotami Europejskimi. Zapoczątkowany w ten sposób proces liberalizacji wymiany handlowej z krajami Wspólnoty doprowadził do powstania w 1999 r. strefy wolnego handlu obejmującej wyroby przemysłowe. Handel artykułami rolnymi został całkowicie zliberalizowany z dniem akcesji krajów UE-10 do Unii Europejskiej. Istotne zmiany struktury geograficznej i towarowej handlu krajów UE-10 zostały zatem rozpoczęte przed akcesją i postępowały po akcesji.

Kształtowanie się struktury wymiany handlowej krajów UE-10 było w znacznej mierze wynikiem realokacji procesów produkcji z uwagi na niższe koszty wytwarzania oraz bliskość geograficzną największych rynków europejskich. Dzięki wykorzystaniu na dużą skalę tych czynników, a także przy zastosowaniu nowoczesnych technologii teleinformatycznych to korporacje międzynarodowe stały się generatorem znacznej części strumieni handlu zagranicznego krajów UE-10.

Ta ekspansja była jedną z przyczyn znaczącego przyspieszenia dynamiki handlu zagranicznego krajów UE-10 oraz wzrostu ich udziału w handlu światowym. W latach 2004-2013 udział krajów UE-10 w światowym eksporcie wzrósł prawie dwukrotnie (z 3,2 do 3,7\%) przy jednoczesnym spadku znaczenia państw UE-15 (udział w światowym eksporcie krajów UE-15 spadł aż o 8,4 pkt proc. z $38,3 \%$ do $29,9 \%)$.

Analizowany proces dynamizowania wymiany handlowej z zagranicą w krajach UE-10 doprowadził w ciągu ostatnich kilkunastu lat do wzrostu stopnia integracji tych państw z gospodarką światową. Otwartość badanych gospodarek, mierzona udziałem wartości eksportu i importu towarów i usług w PKB (w cenach bieżących), wzrosła po akcesji z 104,1 do $125,2 \%$. Wszystkie państwa UE-10 charakteryzowały się w 2013 r. większą otwartością swoich gospodarek niż

${ }^{1} \mathrm{~W}$ celu zagwarantowania lepszej syntezy wniosków z przeprowadzonej analizy badaniem w całym okresie 2004-2013 objęto także Rumunię i Bułgarię, które formalnie przystąpiły do Unii Europejskiej w 2007 r. 
średnio kraje UE-15² (nawet gospodarka Rumunii, najmniej otwarta w 2013 r. spośród wszystkich państw UE-10, charakteryzowała się wskaźnikiem w wysokości 84,9\%)

Mając na uwadze rosnącą rolę handlu zagranicznego w gospodarkach nowych krajów członkowskich, w artykule przedstawione zostały wyniki analizy głównych tendencji w handlu zagranicznym państw UE-10 w okresie 10 lat od największego rozszerzenia Unii Europejskiej (2004-2013). Badanie statystyczne skupiono na analizie dynamiki importu i eksportu, struktury handlu w ramach grup towarowych SITC oraz BEC, wskaźników koncentracji (współczynnik Giniego oraz indeks Herfindahla-Hirschmana), a także podobieństwa struktur wymiany.

\section{Podstawowe tendencje w rozwoju handlu zagranicznego państw UE-10 w latach 2004-2013}

Postępujący proces globalizacji i pogłębiająca się w związku z nim integracja gospodarcza późniejszych państw UE-10 z Unią Europejską skutkowały nie tylko wzrostem otwartości gospodarek na wymianę z zagranicą, ale także zmianami kierunków i intensywności powiązań handlowych poszczególnych krajów z gospodarką światową.

Istotna zmiana struktury geograficznej handlu zagranicznego państw Europy Środkowo-Wschodniej została zapoczątkowana już w latach 90. XX w. Głównymi partnerami w wymianie handlowej stały się kraje wysoko rozwinięte, przede wszystkim państwa członkowskie Unii Europejskiej. Silne powiązania handlowe państw UE-10 z krajami UE-15 były efektem postępującego procesu integracji gospodarczej w okresie przedakcesyjnym, ale także pogłębiających się form współpracy i zachodzących interakcji na szczeblu przedsiębiorstw. Istotna zmiana warunków handlu zagranicznego po akcesji państw UE-10 miała znaczący wpływ na dalsze zmiany w strukturze geograficznej wymiany towarowej.

Jak wynika $\mathrm{z}$ analizy tendencji zestawionych na rys. 1, w badanym okresie można było zauważyć istotne zmiany dynamiki eksportu i importu nowych państw członkowskich w wymianie ze wszystkimi partnerami. Obroty globalne państw UE-10 rosły w latach 2004-2013 znacznie szybciej niż wymiana zagraniczna państw UE-15 - wskaźniki dynamiki wyniosły odpowiednio 218,7\% (wzrost wartości importu i eksportu z 513,8 mld euro do 1124,2 mld euro) oraz 142,2\% (wzrost z 5525,2 mld euro do 7861,6 mld euro).

${ }^{2}$ Wskaźnik otwartości gospodarek państw UE-15 wyniósł w 2004 r. 68,3\%, a w 2013 r. 83,8\%.

3 Niższa otwartość handlowa Polski i Rumunii niż innych państw regionu wynika m.in. z większych rozmiarów ich gospodarek, co oznacza, że większą rolę w kształtowaniu dynamiki PKB odgrywa w ich przypadku popyt wewnętrzny. 
Dynamika wymiany zagranicznej nowych państw członkowskich była znacząco wyższa niż w przypadku krajów UE-15. Dzięki temu w latach 2004-2013 znacząco wzrósł udział eksportu i importu towarów krajów UE-10 w zagregowanym eksporcie i imporcie UE-25. Udział ten zwiększył się prawie dwukrotnie w eksporcie (z 7,9\% w 2004 r. do $12,4 \%$ w 2013 r.) a w imporcie z 9,1 do 12,7\%. Spośród krajów UE-10 najsilniejszy wzrost udziału zarówno eksportu, jak i importu w handlu globalnym krajów UE-25 miał miejsce w Polsce, w Czechach i na Słowacji.

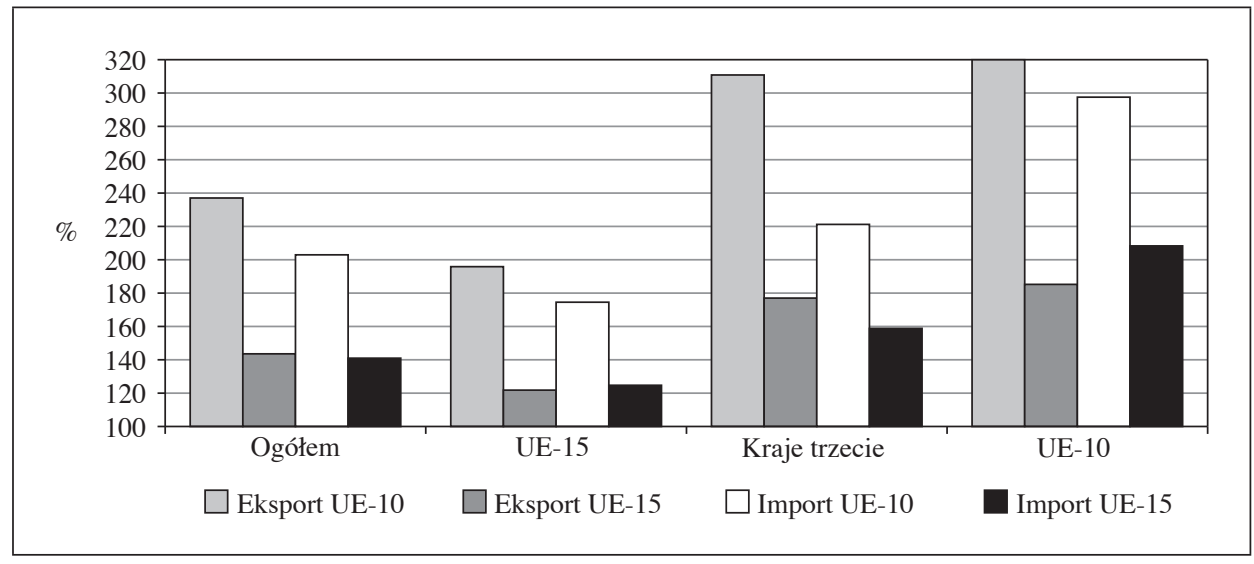

Rys. 1. Dynamika obrotów handlowych krajów UE-10 i UE-15 w latach 2004-2013 $(2004$ r. $=100 \%)$

Źródło: opracowanie własne na podstawie danych Eurostat, baza Easy Comext DS-016894-EU27 Trade Since 1988 By HS2-HS4, http://epp.eurostat.ec.europa.eu/newxtweb/ (dostęp: 9.08.2014).

Spośród badanych relacji największą dynamiką charakteryzowały się wzajemne obroty handlowe krajów UE-10. W latach 2004-2013 zwiększyły się one ponad trzykrotnie (z 72,2 do 222,9 mld euro), w tym eksport - ponad 3,2 razy (z 36,2 do 116,0 mld euro), a import - prawie 3 razy (z 35,9 do 106,9 mld euro). W tym samym okresie obroty krajów UE-10 z krajami UE-15 wzrosły tylko 1,8 razy (z 322,3 do 595,8 mld euro).

Wzajemne obroty handlowe (zarówno eksport, jak i import) państw UE-10 wzrosły w latach 2004-2013 1,6-razy szybciej niż ich obroty z państwami UE-15 i 1,2 razy szybciej niż obroty z krajami trzecimi. Odpowiednie wskaźniki dla eksportu wyniosły 1,63 i 1,03, a dla importu 1,67 i 1,31.

Podobne tendencje wystąpiły również w przypadku każdego z nowych państw członkowskich. Analiza tendencji przedstawianych w tabeli 1 potwierdza, że dla większości z nich powiązania handlowe (eksport i import) z partnerami z grupy 
UE-10 rozwijały się w latach 2004-2013 znacznie szybciej niż ich obroty globalne czy wymiana z UE-15 lub krajami trzecimi.

Tabela 1. Dynamika obrotów handlowych poszczególnych państw UE-10 w latach 2004-2013 według grup krajów $(2004=100 \%)$

\begin{tabular}{|l|c|c|c|c|c|c|c|}
\hline \multirow{2}{*}{ Kraj } & \multirow{2}{*}{ Ogółem } & \multirow{2}{*}{ UE-15 } & \multirow{2}{*}{$\begin{array}{c}\text { Kraje } \\
\text { trzecie }\end{array}$} & UE-10 & \multicolumn{3}{c|}{ Relacja } \\
\cline { 5 - 8 } & & & & $5: 2$ & $5: 3$ & $5: 4$ \\
\hline \multicolumn{7}{|c|}{ Eksport } \\
\hline Bułgaria & 278,4 & 233,5 & 295,6 & 518,5 & 1,86 & 2,22 & 1,75 \\
\hline Czechy & 219,3 & 192,7 & 328,9 & 241,4 & 1,10 & 1,25 & 0,73 \\
\hline Estonia & 257,3 & 212,8 & 382,1 & 270,6 & 1,05 & 1,27 & 0,71 \\
\hline Węgry & 182,1 & 141,3 & 253,8 & 317,3 & 1,74 & 2,25 & 1,25 \\
\hline Litwa & 328,4 & 217,6 & 426,1 & 412,8 & 1,26 & 1,90 & 0,97 \\
\hline Łotwa & 338,0 & 182,3 & 460,0 & 569,6 & 1,69 & 3,12 & 1,24 \\
\hline Polska & 252,2 & 216,5 & 326,7 & 323,9 & 1,28 & 1,50 & 0,99 \\
\hline Rumunia & 261,8 & 216,8 & 310,7 & 453,1 & 1,73 & 2,09 & 1,46 \\
\hline Słowenia & 194,7 & 175,6 & 188,4 & 320,9 & 1,65 & 1,83 & 1,70 \\
\hline Słowacja & 289,9 & 243,5 & 380,1 & 347,5 & 1,20 & 1,43 & 0,91 \\
\hline UE-10 & 237,0 & 195,9 & 310,8 & 319,9 & 1,35 & 1,63 & 1,03 \\
\hline UE-15 & 143,6 & 121,8 & 177,0 & 185,2 & 1,29 & 1,52 & 1,05 \\
\hline & & \multicolumn{7}{|c|}{ Import } & & & \\
\hline Bułgaria & 222,4 & 196,2 & 210,7 & 422,4 & 1,90 & 2,15 & 2,00 \\
\hline Czechy & 192,1 & 161,6 & 233,7 & 281,2 & 1,46 & 1,74 & 1,20 \\
\hline Estonia & 203,9 & 183,6 & 142,1 & 384,8 & 1,89 & 2,10 & 2,71 \\
\hline Węgry & 154,8 & 138,7 & 141,4 & 283,8 & 1,83 & 2,05 & 2,01 \\
\hline Litwa & 266,2 & 222,1 & 292,6 & 321,9 & 1,21 & 1,45 & 1,10 \\
\hline Łotwa & 235,9 & 203,4 & 178,0 & 343,2 & 1,46 & 1,69 & 1,93 \\
\hline Polska & 214,2 & 186,6 & 273,4 & 249,4 & 1,16 & 1,34 & 0,91 \\
\hline Rumunia & 210,3 & 205,9 & 151,6 & 424,6 & 2,02 & 2,06 & 2,80 \\
\hline Słowenia & 176,0 & 132,1 & 339,6 & 199,5 & 1,13 & 1,51 & 0,59 \\
\hline Słowacja & 256,6 & 212,4 & 313,6 & 293,8 & 1,14 & 1,38 & 0,94 \\
\hline UE-10 & 203,0 & 174,5 & 221,2 & 297,5 & 1,47 & 1,70 & 1,34 \\
\hline UE-15 & 141,0 & 124,7 & 158,8 & 208,3 & 1,48 & 1,67 & 1,31 \\
\hline
\end{tabular}

Źródło: opracowanie własne na podstawie danych Eurostat, baza Easy Comext DS-016894-EU27 Trade Since 1988 By HS2-HS4, http://epp.eurostat.ec.europa.eu/newxtweb/ (dostęp: 09.08.2014).

Po akcesji znacząco wzrosło więc znaczenie wzajemnej wymiany handlowej nowych państw członkowskich. Świadczy o tym również istotny wzrost relacji 
wartości obrotów wzajemnych krajów UE-10 do wartości ich wymiany towarowej z UE-15 - w 2004 r. było to $22,3 \%$, a w 2013 r. już 37,4\%. W znacznym stopniu przyczyniła się do tego wymiana realizowana pomiędzy krajami UE-10 wynikająca $\mathrm{z}$ tworzonych przez korporacje międzynarodowe sieci dostaw w regionie. Realokacja procesów produkcji do krajów regionu na coraz większą skalę wpływała na substytucję handlu z krajami UE-15 wymianą wzajemną, w szczególności w handlu dobrami pośrednimi. Co więcej, jak wynika z analizy statystyk dotyczących wartości dodanej, na dynamizowanie wzajemnego handlu pomiędzy nowymi krajami członkowskimi wpływała istotnie zagraniczna wartość dodana, pochodząca przede wszystkim z krajów UE-15 [Sytuacja gospodarcza... 2014, s. 40-47].

W analizie obejmującej okres 10 lat członkostwa krajów UE-10 w Unii uzasadnione wydaje się wyróżnienie 2 przedziałów: okres pierwszych lat po akcesji (2004-2008) i okres globalnego kryzysu i recesji (2009-2013).

W latach 2004-2013 wartość eksportu i importu towarów krajów UE-10 wykazywała tendencję rosnącą. Wyjątek stanowił jedynie 2009 r. z powodu zapoczątkowanego wówczas w USA kryzysu finansowego, który przeniósł się w skali globalnej do większości gospodarek, w tym również krajów Europy Środkowo-Wschodniej. Dodatkowo w 2012 r. problemy ekonomiczne w strefie euro będące następstwem kryzysu zadłużenia krajów PIIGS miały przełożenie na wymianę handlową państw Unii Europejskiej, w tym także niektórych krajów EU-10 ${ }^{4}$.

W następstwie zawirowań wywołanych globalnym kryzysem ekonomicznym doszło m.in. do istotnych zmian tendencji rozwoju wymiany zagranicznej nowych państw członkowskich. Wymiana towarowa nowych krajów członkowskich, jaka przypadła na badane lata kryzysu, rozwijała się z dużo mniejszą dynamiką niż w pierwszych latach członkostwa - dla eksportu ogółem wskaźnik spadł z 185,2\% (za lata 2004-2008) do 156,1\% (w okresie 2009-2013), a dla importu z 186,3 do $147,0 \%$.

Warto zwrócić przy tym uwagę, że po 2009 r. dynamikę obrotów krajów UE-10 w największym stopniu stymulował eksport do krajów trzecich ${ }^{5}$. Najbardziej podatne na kryzys okazały się natomiast wzajemne powiązania handlowe państw UE-10 - w przypadku tej relacji został zaobserwowany największy spadek

${ }^{4}$ Przyczyny i skutki globalnego kryzysu gospodarczego zostały przedstawione m.in. w publikacjach: [Ambroziak i Błaszczuk-Zawiła 2011, Czarny i Syczewska 2011, Czarny i Śledziewska 2012, Goetz 2012, Kuśpit i Pasierbiak 2011, Miklaszewski 2011, Molendowski i Polan 2010, Pera 2012a, 2012b].

5 Najwyższe wskaźniki dynamiki eksportu krajów UE-10 w latach 2009-2013 wystąpiły w wymianie handlowej z Australią (283\%), Brazylią (235\%), Chinami (213\%) oraz USA (189\%). Wartościowo największe przyrosty eksportu w tym okresie miały miejsce z Rosją (15,4 mld euro), USA (5 mld euro) i Chinami (4 mld euro). 
dynamiki rozwoju zarówno eksportu, jak i importu (wskaźniki dynamiki za lata 2009-2013 były niższe od tych za lata 2004-2008 o ponad 30\%). W warunkach kryzysu najbardziej stabilne okazały się relacje handlowe państw UE-10 z krajami UE-15. W przypadku tej relacji wskaźniki dynamiki za lata 2009-2013 były niższe od tych za lata 2004-2008 jedynie o 12,9\% dla eksportu i 17,0\% dla importu. Tendencje te są wyraźnie widoczne na rys. 2.

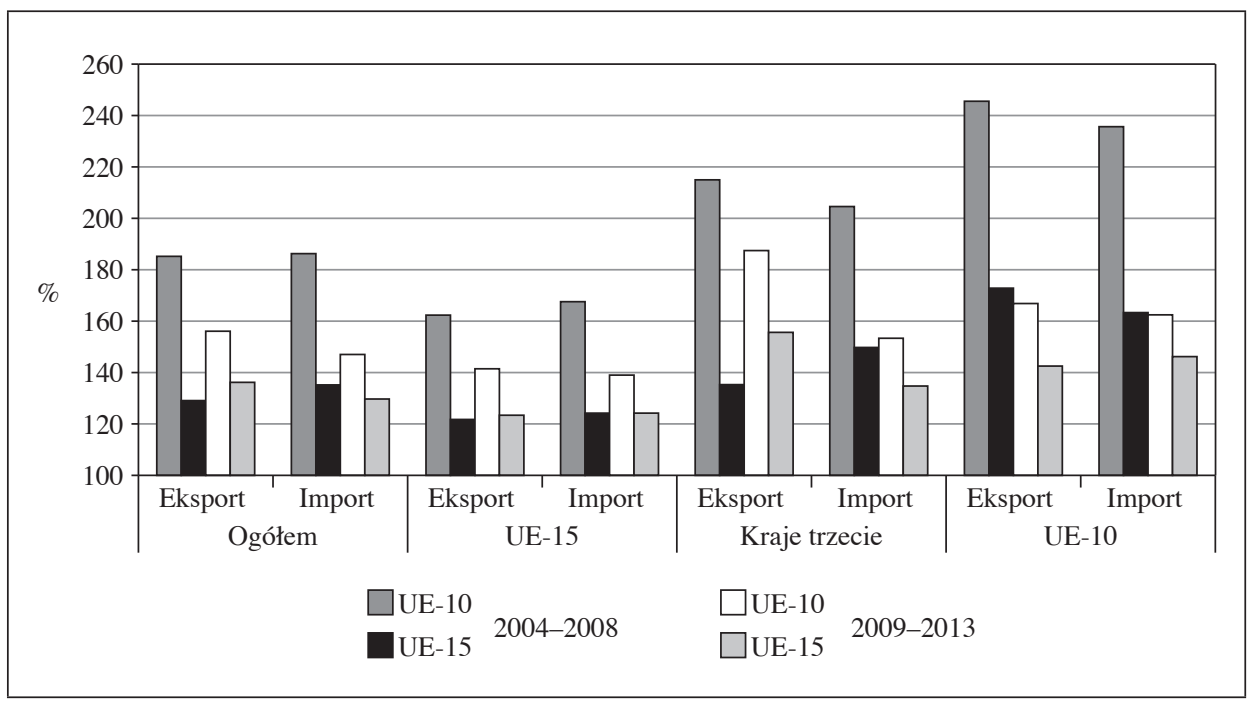

Rys. 2. Dynamika obrotów handlowych krajów UE-10 i UE-15 w latach 2004-2008 oraz 2009-2013

Źródło: opracowanie własne na podstawie danych Eurostat, baza Easy Comext DS-016894-EU27 Trade Since 1988 By HS2-HS4, http://epp.eurostat.ec.europa.eu/newxtweb/ (dostęp: 9.08.2014).

Przedstawione dane potwierdzają słuszność tezy, że zmiana warunków handlu będąca wynikiem akcesji państw UE-10 do Unii Europejskiej przyczyniła się do istotnego zwiększenia dynamiki ich wzajemnych powiązań handlowych.

Rynek krajów UE-10 stał się w analizowanym okresie dla poszczególnych państw UE-10 znaczącym obszarem sprzedaży produkowanych w tych państwach towarów oraz zaspokajania popytu importowego ich gospodarek i konsumentów. Było to możliwe m.in. dzięki ujednoliceniu wzorów dotyczących rozwoju wymiany handlowej krajów UE-10 i UE-15. W latach 2004-2013 doszło bowiem do największego zdynamizowania obrotów w relacji z krajami UE-10, następnie z krajami trzecimi, a w najmniejszym stopniu z partnerami z UE-15.

$\mathrm{Na}$ tej podstawie można również stwierdzić, że wynikający z procesów liberalizacji i integracji handlowej dynamiczny rozwój handlu w ramach UE-10 zapobiegł powstaniu tzw. efektu piasty i szprych (hub-and-spoke), czyli tendencji 
do szybszego rozwoju relacji pomiędzy partnerem silniejszym (UE-15 - centrum, piasta) niż pomiędzy „szprychami” (poszczególnymi krajami UE-10) ${ }^{6}$.

\section{Analiza koncentracji oraz podobieństwa struktury towarowej eksportu i importu nowych krajów członkowskich}

W latach 2004-2012 nastąpiła istotna zmiana struktury wymiany towarowej krajów UE-10. W 2004 r. największe znaczenie w eksporcie i imporcie tych krajów miały wyroby klasyfikowane jako maszyny i pojazdy - ich udział w eksporcie i imporcie wyniósł odpowiednio $43,7 \%$ oraz $40,6 \%$ (por. tabela 2). Wynikało to z faktu, że napływ bezpośrednich inwestycji zagranicznych w tym regionie związany z ekspansją korporacji międzynarodowych jeszcze przed akcesją skoncentrowany był głównie na sektorach maszynowym i motoryzacyjnym.

Po przystąpieniu krajów UE-10 do Unii utrzymała się wysoka dynamika eksportu maszyn i pojazdów - udział tej grupy towarowej wzrósł z 43,7\% w 2004 r. do 46,0\% w 2008 r. Po kryzysie w 2009 r. miało miejsce obniżenie się znaczenia tej grupy w eksporcie - odnotowano jej udział na poziomie 43,8\% w 2013 r. Było to związane m.in. z osłabieniem aktywności korporacji międzynarodowych w tym sektorze. W tym samym czasie w eksporcie zwiększyła się rola grup towarów o niższym stopniu przetworzenia - udział artykułów rolno-spożywczych, surowców i paliw w eksporcie krajów UE-10 wzrósł w latach 2004-2013 z 13,9 do 18,5\%.

W jeszcze większym stopniu w okresie po akcesji (2004-2013) wzrosło znaczenie produktów nieprzetworzonych w imporcie krajów UE-10 - odnotowano wzrost ich udziału z 17,0 do 24,4\%. Zmiany te stymulowane były głownie przez dużą dynamikę importu paliw (ponad trzykrotny wzrost wartości z 23 do 73 mld euro). Wzrost znaczenia produktów nieprzetworzonych w handlu zagranicznym państw UE-10 przełożył się m.in. na zwiększenie udziału w eksporcie i imporcie tych krajów dóbr finalnych (w eksporcie z 28,9\% w 2004 r. do 30,3\% w 2013 r., a w imporcie z 21,8 do 23,0\%).

Proces upodabniania się struktury handlu krajów UE-10 do wzorów wymiany funkcjonujących w Unii znalazł swoje odzwierciedlenie m.in. w zmniejszeniu udziału w latach 2004-2013 produktów przemysłowych zarówno w eksporcie, jak i w imporcie globalnym krajów UE-10 oraz UE-15. Warto przy tym zwrócić uwagę, że w handlu produktami przemysłowymi krajów UE-10 znacząco spadł

${ }^{6}$ Efekt piasty i szprych został opisany przez R. Wonacotta [1996] dla przedstawienia skutków umów zawartych w latach 90. XX w. przez Wspólnoty Europejskie z krajami EŚW oraz państwami basenu Morza Śródziemnego. Prawidłowość tę potwierdzili również L. De Benedictis, R. De Santis i C. Vicarelli [2005]. E. Molendowski [2007] dowiódł braku występowania tego zjawiska w relacjach CEFTA-UE w latach 1993-2003. 
Główne tendencje w handlu zagranicznym nowych państw...

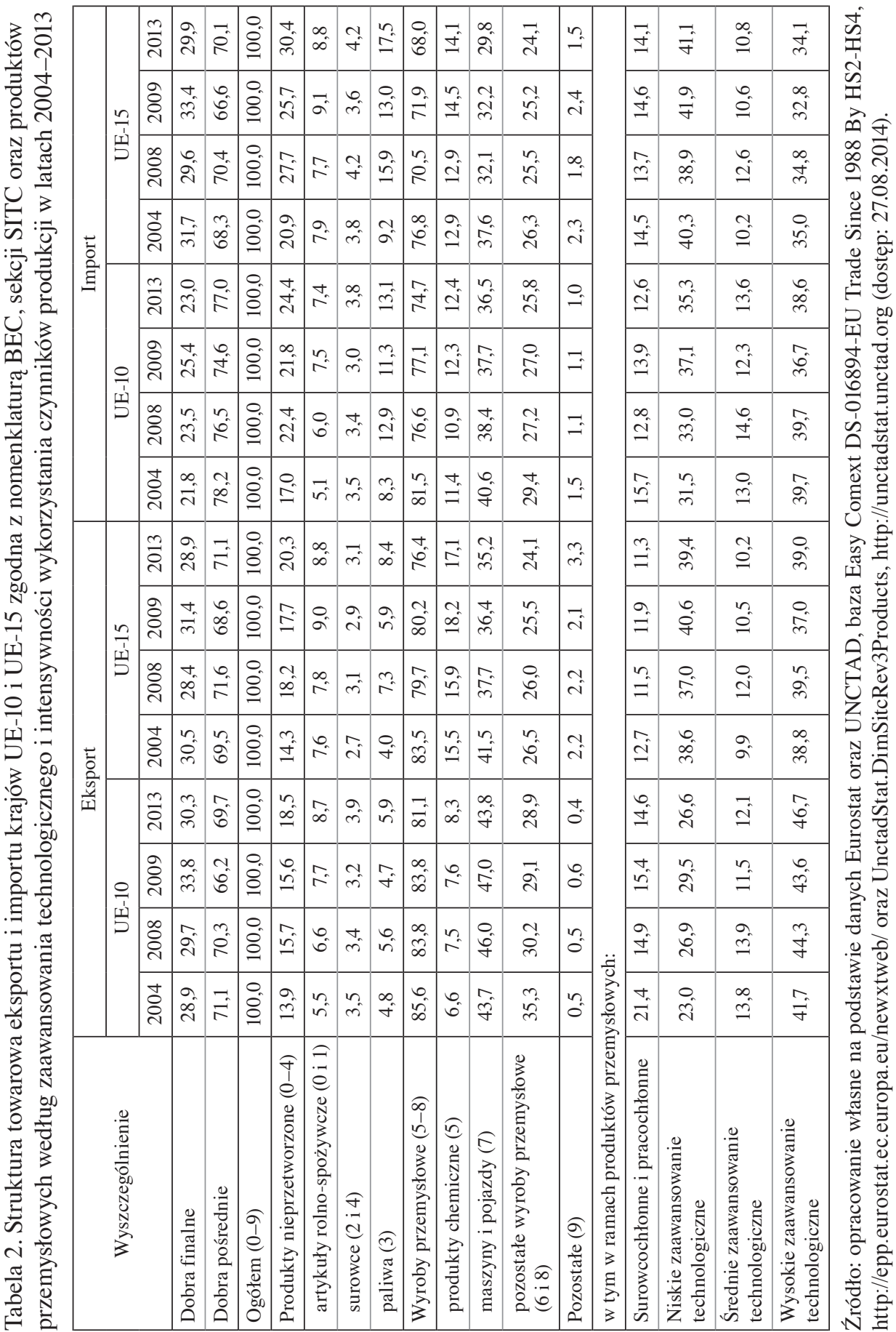


w latach 2004-2013 udział produktów surowcochłonnych i pracochłonnych. O rosnącej konkurencyjności eksportu krajów UE-10 świadczyć może ponadto istotny wzrost udziału w nim handlu produktami o wysokim stopniu zaawansowania technologicznego i dużym wykorzystaniu kapitału ludzkiego.

Badanie wskaźników stopnia koncentracji grup towarowych eksportu pomiędzy 2004 a 2013 r. wykazało jej umiarkowany wzrost dla krajów UE-10 (zob. tabela 3). W przypadku tej grupy państw udział 5 największych grup towarowych wzrósł z 50,7\% w 1999 r. do 52,1\% w 2013 r. W tym samym okresie w krajach UE-15 nastąpiło nieznaczne osłabienie koncentracji eksportu w największych grupach towarowych (spadek z 47,4 do 46,4\%).

Analizując wskaźniki obliczone dla poszczególnych państw UE-10, można zauważyć, że w 5 krajach wzrósł udział w eksporcie 5 największych grup towarowych - w największym stopniu na Słowacji i w Czechach, następnie w Bułgarii, Estonii i Rumunii, natomiast w przypadku pozostałych 5 krajów (Łotwa, Węgry, Polska, Litwa i Słowenia) badane wskaźniki koncentracji miały w 2013 r. niższe wartości niż w $2004 \mathrm{r}$.

Na wzrost koncentracji eksportu wskazują także zmiany wskaźników syntetycznych. Współczynniki Giniego oraz Herfindahla-Hirschmana dla gospodarek krajów UE-10 zwiększyły się w okresie 2004-2013 ( $G$ z 0,84 w 2004 r. do 0,85 w 2013 r. oraz $H H$ z 0,010 do 0,013$)$.

Analiza stopnia koncentracji importu krajów UE-10 w latach 2004-2013 wykazała - podobnie jak to miało miejsce w przypadku eksportu - jej niewielki wzrost. Udział 5 największych grup towarowych w imporcie wzrósł z 52,7\% w 2004 r. do 53,8\% w 2013 r. Badanie potwierdziło podobną tendencję w przypadku krajów UE-15 - również dla tej grupy państw nastąpiło nieznaczne wzmocnienie zakresu koncentracji importu w największych grupach towarowych (wzrost z 48,2 do 49,7\%). W 8 krajach udział 5 największych grup towarowych w imporcie wzrósł w największym stopniu w Bułgarii, na Litwie, w Słowacji i w Czechach. Jedynie w przypadku 2 krajów (Polski i Węgier) wskaźnik ten był w 2013 r. mniejszy niż w 1999 r. Na wzrost koncentracji importu państw UE-10 w ramach badanych grup towarowych wskazuje również analiza zmian wybranych wskaźników syntetycznych. Obydwa badane współczynniki zwiększyły się w okresie 2004-2013 ( $G$ z 0,81 do 0,83 oraz $\mathrm{HH} \mathrm{z} 0,008$ do 0,011 ).

Dokonując analizy zmian zachodzących w wymianie handlowej nowych państw członkowskich na jednolitym rynku europejskim, należy wziąć pod uwagę także badanie wskaźników podobieństwa struktur ich wymiany ukierunkowanej na rynki krajów UE-10 i UE-15. 
Tabela 3. Mierniki koncentracji dla struktury wymiany towarowej gospodarek krajów UE-10 w latach 2004-2013

\begin{tabular}{|c|c|c|c|c|c|c|c|c|c|c|c|c|}
\hline \multirow{2}{*}{$\begin{array}{l}\text { Wyszcze- } \\
\text { gólnienie }\end{array}$} & \multicolumn{4}{|c|}{$\begin{array}{l}\text { Udział } 5 \text { największych } \\
\text { grup towarowych (w\%) }\end{array}$} & \multicolumn{4}{|c|}{ Współczynnik Giniego } & \multicolumn{4}{|c|}{$\begin{array}{c}\text { Współczynnik } \\
\text { Herfindahla-Hirschmana }\end{array}$} \\
\hline & 2004 & 2008 & 2009 & 2013 & 2004 & 2008 & 2009 & 2013 & 2004 & 2008 & 2009 & 2013 \\
\hline \multicolumn{13}{|c|}{ Eksport } \\
\hline Bułgaria & 43,0 & 46,9 & 41,9 & 45,7 & 0,88 & 0,88 & 0,87 & 0,91 & 0,019 & 0,027 & 0,018 & 0,026 \\
\hline Czechy & 57,9 & 62,7 & 61,2 & 61,4 & 85 & 085 & 085 & 0,89 & 0,015 & 0,017 & 0,020 & 0,021 \\
\hline Estonia & 52,9 & 49,4 & 52,1 & 53,3 & & 087 & 0,87 & 0,90 & 0,021 & 0,017 & 0,025 & 0,022 \\
\hline Litwa & 49,7 & 49,2 & 45,1 & 47,6 & 0,90 & 0,88 & 0,87 & 0,89 & 0,056 & 0,058 & 0,044 & 0,053 \\
\hline Łotwa & 52,4 & 46,8 & 44,1 & 45,5 & 0,90 & 0,85 & 0,85 & 0,89 & 0,034 & 0,012 & 0,012 & 0,012 \\
\hline Polska & 47,0 & 49,1 & 50,3 & 44,4 & 0,85 & 0,84 & 0,84 & 0,87 & 0,013 & 0,012 & 0,014 & 0,009 \\
\hline Rumunia & 48,7 & 48,7 & 49,9 & 48,9 & & 0,89 & 0,89 & 0,91 & 0,019 & 0,018 & 0,018 & 0,018 \\
\hline Słowacja & 59,8 & 66,1 & 65,1 & 68,0 & & 0,89 & 0,88 & 0,93 & 0,033 & 0,043 & 0,044 & 0,045 \\
\hline Słowenia & 51,5 & 52,3 & 53,2 & 50,8 & 0,00 & 0,86 & 0,87 & 0,91 & 0,019 & 0,023 & 0,028 & 0,019 \\
\hline Węgry & 67,4 & 67,3 & 67,0 & 61,0 & 0,89 & 0,88 & 0,88 & 0,91 & 0,021 & 0,024 & 0,027 & 0,016 \\
\hline UE-10 & 50,7 & 55,0 & 54,1 & 52,1 & 0,84 & 0,84 & 0,84 & 0,85 & 0,010 & 0,013 & 0,015 & 0,013 \\
\hline UE-15 & 47,4 & 47,9 & 46,4 & 46,4 & 0,19 & 0,78 & 0,78 & 0,82 & 0,011 & 0,009 & 0,009 & 0,010 \\
\hline \multicolumn{13}{|c|}{ Import } \\
\hline Bułgaria & 47,4 & 55,7 & 49,6 & 52,2 & 0,82 & 0,83 & 0,82 & 0,87 & 0,029 & 0,025 & 0,020 & 0,027 \\
\hline Czechy & 53,4 & 57,1 & 55,6 & 56,9 & 0,81 & 0,82 & 0,82 & 0,86 & 0,008 & 0,010 & 0,010 & 0,011 \\
\hline Estonia & 49,6 & 52,3 & 48,3 & 52,2 & 0,81 & 0,82 & 0,81 & 0,86 & 0,010 & 0,022 & 0,027 & 0,016 \\
\hline Litwa & 51,8 & 56,0 & 50,7 & 55,9 & 0,83 & 0,85 & 0,84 & 0,88 & 0,030 & 0,052 & 0,052 & 0,054 \\
\hline Łotwa & 45,0 & 48,5 & 43,2 & 45,1 & & 0,81 & 0,80 & 0,84 & 0,014 & 0,015 & 0,014 & 0,015 \\
\hline Polska & 50,3 & 50,8 & 48,7 & 48,4 & 0,80 & 0,80 & 0,79 & 0,85 & 0,009 & 0,012 & 0,010 & 0,013 \\
\hline Rumunia & 48,1 & 52,9 & 47,9 & 49,9 & 0,80 & 0,80 & 0,79 & 0,84 & 0,009 & 0,012 & 0,010 & 0,010 \\
\hline Słowacja & 55,7 & 59,7 & 58,4 & 59,4 & 0,81 & 0,85 & 0,84 & 0,89 & 0,014 & 0,018 & 0,017 & 0,020 \\
\hline Słowenia & 48,2 & 52,5 & 47,8 & 49,7 & 0,80 & 0,81 & 0,80 & 0,86 & 0,011 & 0,018 & 0,015 & 0,019 \\
\hline Węgry & 63,6 & 65,6 & 64,3 & 62,6 & 0,84 & 0,85 & 0,84 & 0,88 & 0,012 & 0,014 & 0,014 & 0,013 \\
\hline UE-10 & 52,7 & 55,5 & 53,2 & 53,8 & 0,81 & 0,81 & 0,75 & 0,83 & 0,008 & 0,010 & 0,009 & 0,011 \\
\hline UE-15 & 48,2 & 50,1 & 48,1 & 49,7 & 0,79 & 0,80 & 0,80 & 0,83 & 0,011 & 0,013 & 0,011 & 0,014 \\
\hline
\end{tabular}

Źródło: opracowanie własne na podstawie danych Eurostat na 3. poziomie dezagregacji klasyfikacji $\mathrm{CN}(\mathrm{CN} 4)$ oraz danych na 2. poziomie dezagregacji klasyfikacji CN (CN2), baza Easy Comext DS016894-EU Trade Since 1988 By HS2-HS4, http://epp.eurostat.ec.europa.eu/newxtweb/ (dostęp: 24.07.2014). 
Analiza obliczonych mierników podobieństwa ${ }^{7}$ wykazała, że w latach 20042013 nastąpiło przybliżenie struktur importu niemal wszystkich krajów UE-10 w ich handlu wzajemnym do struktury ich importu do krajów UE-15 (wyjątkiem była Słowacja). Do 2013 r. największe zbliżenie struktur spośród wszystkich państw UE-10 nastąpiło w przypadku Czech (spadek wartości wskaźnika o 0,033), a także Estonii, Łotwy i Słowenii (spadek odpowiednio o 0,030, 0,029 i 0,028) por. tabela 4.

Tabela 4. Wskaźniki podobieństwa struktur eksportu i importu (według odległości euklidesowej) w handlu wzajemnym krajów UE-10 oraz z państwami UE-15

\begin{tabular}{|l|c|c|c|c|c|c|c|c|}
\hline \multirow{2}{*}{ Wyszczególnienie } & \multicolumn{4}{|c|}{ Import } & \multicolumn{4}{c|}{ Eksport } \\
\cline { 2 - 9 } & 2004 & 2008 & 2009 & 2013 & 2004 & 2008 & 2009 & 2013 \\
\hline Bułgaria & 0,143 & 0,124 & 0,109 & 0,121 & 0,170 & 0,119 & 0,106 & 0,125 \\
\hline Czechy & 0,107 & 0,084 & 0,081 & 0,074 & 0,092 & 0,079 & 0,096 & 0,080 \\
\hline Estonia & 0,159 & 0,258 & 0,213 & 0,129 & 0,160 & 0,168 & 0,132 & 0,214 \\
\hline Litwa & 0,080 & 0,085 & 0,078 & 0,077 & 0,203 & 0,094 & 0,170 & 0,172 \\
\hline Łotwa & 0,147 & 0,158 & 0,129 & 0,117 & 0,276 & 0,149 & 0,152 & 0,174 \\
\hline Polska & 0,096 & 0,072 & 0,081 & 0,082 & 0,098 & 0,077 & 0,107 & 0,068 \\
\hline Rumunia & 0,090 & 0,077 & 0,068 & 0,066 & 0,139 & 0,138 & 0,129 & 0,094 \\
\hline Słowacja & 0,104 & 0,077 & 0,080 & 0,117 & 0,182 & 0,194 & 0,188 & 0,219 \\
\hline Słowenia & 0,092 & 0,082 & 0,088 & 0,064 & 0,178 & 0,138 & 0,165 & 0,130 \\
\hline Węgry & 0,100 & 0,097 & 0,095 & 0,088 & 0,103 & 0,075 & 0,096 & 0,100 \\
\hline UE-10 $^{\text {a }}$ & 0,112 & 0,111 & 0,102 & 0,094 & 0,160 & 0,123 & 0,134 & 0,138 \\
\hline
\end{tabular}

a średnia arytmetyczna.

Źródło: opracowanie własne na podstawie danych Eurostat na 3. poziomie dezagregacji klasyfikacji CN (CN4), baza Easy Comext DS-016894-EU Trade Since 1988 By HS2-HS4, http://epp.eurostat. ec.europa.eu/newxtweb/ (dostęp: 1.08.2014).

$7 \mathrm{~W}$ analizie skupiono się na określeniu odległości euklidesowej pomiędzy strukturami z wykorzystaniem miernika liczonego według następującego wzoru:

$$
e_{j}=\left(\sum_{i=1}^{n}\left|\alpha_{i j}-\beta_{i j}\right|^{2}\right)^{\frac{1}{2}},
$$

gdzie: $\alpha_{i j}$-udział danej grupy towarowej (oznaczonej kodem $\mathrm{CN}-4$ ) w eksporcie lub imporcie danego kraju do partnera $1 ; \beta_{i j}$ - udział danej grupy towarowej (oznaczonej kodem CN-4) w eksporcie lub imporcie danego kraju do partnera $2 ; i$ - grupy towarowe według pozycji taryfy celnej w dezagregacji 4-cyfrowej; $n$ - liczba badanych grup towarowych (oznaczonych kodami CN-4); $j$ - rok z badanego przedziału 2004-2013. Wskaźnik odległości euklidesowej mierzony powyższym wzorem przyjmuje wartości od 0 do 1 . Gdy przyjmuje on wartości zbliżone do 1 , oznacza to, że większy jest stopień zróżnicowania badanych struktur. Im bardziej wartość obliczonego wskaźnika zbliża się do 0 , tym analizowane struktury są bardziej do siebie zbliżone. 
W latach 2004-2013 również miało miejsce upodobnienie się struktury eksportu niemal wszystkich badanych krajów UE-10 w ich handlu wzajemnym do struktury ich eksportu z krajami UE-15 (z wyjątkiem Estonii i Słowacji). Największe zbliżenie struktur eksportu miało miejsce w przypadku Łotwy i Słowenii (spadek wartości wskaźnika odpowiednio o 0,102 i 0,048), a także Rumunii i Bułgarii (zmiana o 0,045).

Przedstawione tendencje potwierdziły tezę, że eksporterzy z większości nowych krajów członkowskich, których transakcje miały wpływ na kształtowanie się struktur eksportu, w coraz większym stopniu wykorzystywali możliwość sprzedaży swoich produktów zarówno na rynkach krajów UE-10, jak i w ramach powiązań z krajami UE-15.

Wcześniejsze analizy ewolucji specjalizacji nowych państw członkowskich i ich konwergencji w kierunku struktury wymiany handlowej charakterystycznej dla krajów UE-15 wykazały, że proces dostosowań struktury handlu jest długotrwały i ciągły. Jednocześnie postępująca adaptacja nie wykazywała charakterystycznych cech wspólnych dla ówczesnych krajów kandydujących [De Benedictis i Tajoli 2003]. Przedstawione wyniki analizy obrazują tendencje zbliżania się struktur wymiany handlowej krajów UE-10 w ich wymianie wzajemnej do analogicznych struktur w przypadku krajów UE-15. Mogą one być potwierdzeniem tezy, że w pierwszych latach członkowstwa w UE rynki krajów UE-10 i UE-15 traktowane były przez importerów i eksporterów z krajów UE-10 w coraz większym zakresie jako jednolity rynek.

Postępująca liberalizacja handlu i jego dynamiczny wzrost pozwalały producentom, inwestorom oraz eksporterom i importerom z nowych krajów członkowskich na podejmowanie decyzji, w których uwzględniali oni potrzeby nie tylko rynku wewnętrznego, ale również około 500 mln konsumentów z krajów UE-10 i UE-15. Upodabnianie się struktur wymiany handlowej może być potwierdzeniem tezy, że w praktyce decyzje te w taki właśnie sposób były podejmowane w latach 2004-2013 w coraz większym zakresie. Świadczy to również o tym, że producenci i eksporterzy pochodzący z krajów UE-10 z każdym rokiem stawali się coraz lepiej przygotowani do wymogów jednolitego rynku UE.

\section{Podsumowanie}

Badanie dynamiki eksportu i popytu wewnętrznego potwierdziło rosnącą rolę handlu zagranicznego jako jednego z istotnych czynników rozwoju gospodarczego krajów UE-10. Rosnący udział nowych państw członkowskich w światowym eksporcie oraz większa otwartość badanych gospodarek świadczą o wzroście integracji tych krajów z gospodarką światową po akcesji do Unii. 
Analiza zmian w strukturze handlu krajów UE-10 w latach 2004-2013 wykazała istotne zmiany w ramach wymiany towarowej. Wzrosło m.in. znaczenie produktów nieprzetworzonych i dóbr finalnych. Nastąpiło przyspieszenie dynamiki importu paliw, a z drugiej strony doszło do spadku znaczenia handlu towarami przemysłowymi. Wzrosła konkurencyjność eksportu krajów UE-10, na co wskazuje rosnący udział w całkowitym eksporcie eksportu dobrami o wysokim stopniu zaawansowania technologicznego i wykorzystania kapitału ludzkiego.

Badanie udziału w całkowitym eksporcie największych grup towarowych oraz wskaźników syntetycznych (Giniego oraz Herfindahla-Hirschmana) pozwoliło wykazać wzrost koncentracji wymiany towarowej. Wyniki analizy podobieństwa struktur eksportu i importu krajów UE-10 w wymianie wzajemnej i z krajami UE-15 dały podstawy do oceny, że po akcesji do Unii w krajach UE-10 nastąpiły istotne przekształcenia, w wyniku których eksporterzy i importerzy z krajów UE-10 są lepiej przygotowani do współpracy i konkurencji z partnerami z krajów UE-10 i UE-15 w ramach jednolitego rynku europejskiego.

Liberalizacja wymiany pomiędzy krajami uczestniczącymi poszerza rynek, wpływa na zwiększenie skali produkcji, intensyfikuje - często bardziej dochodową - działalność eksportową, a dzięki większemu importowi umożliwia konsumentom większy wybór dóbr (substytutów) i przekłada się na wzmożoną konkurencję na rynkach krajowych, wymuszając dalszy wzrost efektywności ekonomicznej krajowych przedsiębiorstw.

W tym ujęciu akcesja do Unii Europejskiej oznaczała bardzo istotną zmianę warunków handlu nowych państw członkowskich zarówno w relacji z pozostałymi krajami UE-10, jak i z krajami UE-15 oraz krajami trzecimi. Analiza głównych tendencji w handlu zagranicznym w okresie 10 lat od wschodniego rozszerzenia (2004-2013) pozwoliła wnioskować, że zmiany strukturalne będące wynikiem procesu liberalizacji handlu w ramach integracji z Unią Europejską wymiernie przyczyniły się do poprawy pozycji konkurencyjnej państw UE-10.

\section{Literatura}

Ambroziak Ł., Błaszczuk-Zawiła M. [2011], Zmiany w handlu oraz wspótpracy inwestycyjnej Polski z państwami bałtyckimi i Europy Wschodniej w świetle recesji globalnej 2008-2009 [w:] Kryzys gospodarczy 2008-2009 w Europie Wschodniej i państwach bałtyckich, red. K. Falkowski, Oficyna Wydawnicza SGH, Warszawa.

Czarny E., Syczewska E.M. [2011], Gospodarki Unii Europejskiej, strefy euro oraz wybranych państw członkowskich w czasie kryzysu gospodarczego [w:] Handel i wspótpraca międzynarodowa w warunkach kryzysu gospodarczego, red. S. Wydymus, M. Maciejewski, Uniwersytet Ekonomiczny w Krakowie, Fundacja UEK, Kraków.

Czarny E., Śledziewska K. [2012], Międzynarodowa wspótpraca gospodarcza w warunkach kryzysu, PWE, Warszawa. 
De Benedictis L., De Santis R., Vicarelli C. [2005], Hub-and-spoke or Else? Free Trade Agreements in the 'Enlarged' European Union, ,European Journal of Comparative Economics", vol. 2(2).

De Benedictis L., Tajoli L. [2003], Economic Integration, Similarity and Convergence in the EU and CEECs Trade Structures, Flowenla Discussion Paper No. 4, Hamburgisches Welt-Wirtschafts-Archiv, Hamburg Institute of International Economics, Hamburg.

Goetz M. [2012], Kryzys i przyszłość strefy euro, Difin, Warszawa.

Kuśpit J., Pasierbiak P. [2011], Wpływ kryzysu na popyt wewnętrzny i handel zagraniczny [w:] Gospodarka i polityka makroekonomiczna strefy euro w latach 2008-2010. Skutki i słabości zarzadzania, red. B. Mucha-Leszko, Wydawnictwo UMCS, Lublin.

Miklaszewski S. [2011], Konsekwencje światowego kryzysu dla rozwoju integracji Unii Europejskiej [w:] Natura i różnorodność przebiegu światowego kryzysu gospodarczego, red. S. Miklaszewski, J. Garlińska-Bielawska, J. Pera, Difin, Warszawa.

Molendowski E. [2007], Liberalizacja wymiany handlowej krajów Europy Środkowowschodniej w okresie transformacji (ze szczególnym uwzględnieniem doświadczeń krajów CEFTA), Wydawnictwo Uniwersytetu Ekonomicznego w Krakowie, Kraków.

Molendowski E., Polan W. [2010], The Countries of Central and Eastern Europe: Did Accession to EU Help to Overcome the Effects of Global Crisis?, „Gentes \& Nationes”, nr 2/2010.

Pera B. [2012a], Międzynarodowa wymiana towarowa w okresie wspótczesnego kryzysu globalnego [w:] Handel międzynarodowy w warunkach kryzysu gospodarczego. Implikacje dla Polski, red. S. Wydymus, E. Bombińska, B. Pera, CeDeWu.pl, Warszawa.

Pera B. [2012b], Wymiana handlowa krajów Unii Europejskiej a globalny kryzys finansowy, „Prace Naukowe Uniwersytetu Ekonomicznego we Wrocławiu”, nr 267.

Sytuacja gospodarcza w krajach Europy Środkowej $i$ Wschodniej [2014], nr 1/14, NBP, Warszawa.

Wonnacott R.J. [1996], Trade and Investment in a Hub-and-spoke System vs. a Free Trade Area, „World Economy”, vol. 19, nr 3, http://dx.doi.org/10.1111/j.1467-9701.1996. tb00676.x.

\section{Major Trends in Foreign Trade of the New Member States (EU-10) after Their Accession to the European Union}

(Abstract)

The aim of the article was to present the results of an analysis of major trends in foreign trade in the 10-year period following the largest eastern EU enlargement (20042013). Accession to the European Union meant a significant change in New Member States' trade terms, both with other accession countries and EU-15 and third countries. The analysis focuses on the growing role of foreign trade as one of the important factors of economic development of the EU-10 and the increased integration of these countries into the global economy after accession. The statistical aspect of the study focused on the analysis of import and export growth (flows and dynamics), the structure of trade by SITC and BEC commodity groups, concentration indicators (such as the Gini coefficient and the Herfindahl-Hirschman Index) and the similarity of the structures of exchange. 
The conclusions from this research enabled the identification of arguments for the thesis that structural changes which resulted from trade liberalisation within the EU integration processes helped improve the international competitive position of the EU-10 states.

Keywords: foreign trade, European integration, trade liberalization, trade structure. 